Original Scientific Article

\title{
CLINICAL TESTING OF COMBINED VACCINE AGAINST ENZOOTIC PNEUMONIA IN INDUSTRIAL PIG FARMING IN BULGARIA
}

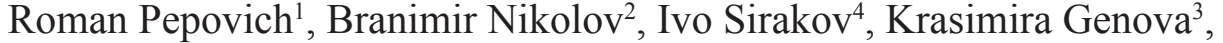 \\ Kalin Hristov ${ }^{2}$, Elena Nikolova ${ }^{4}$, Radka Hajiolova ${ }^{5}$, Boika Beltova ${ }^{5}$ \\ ${ }^{1}$ Department of Infectious Pathology \& Hygiene, Technology and Control of Food of \\ Animal Origin, Faculty of Veterinary Medicine, University of Forestry, Sofia, Bulgaria \\ ${ }^{2}$ Department of Obstetrics, Gynecology, Biotechnology of Reproduction \& \\ Pathological Anatomy and Biochemistry, Faculty of Veterinary Medicine, \\ University of Forestry, Sofia, Bulgaria \\ ${ }^{3}$ Department of Animal Breeding Science, Faculty of Veterinary Medicine, \\ University of Forestry, Sofia, Bulgaria \\ ${ }^{4}$ Department of Virology and Viral Diseases, National Diagnostic and \\ Research Veterinary Institute, Sofia, Bulgaria \\ ${ }^{5}$ Department of Pathophysiology, Faculty of Medicine, Medical University, Sofia, Bulgaria
}

Received 27 April 2015; Received in revised form 10 July 2015; Accepted 13 July 2015

\begin{abstract}
In the pig farm with signs of a respiratory disease complex and laboratory confirmed enzootic pneumonia, the prophylactic efficacy of the combination vaccine $(M$. hyo $+P C V 2)$, a single injection administered intramuscularly 21 days after birth, at a dose of $2 \mathrm{ml}$ was tested. The clinical condition, pathological changes in the lungs and some epidemiological and economic results were reported. It was found that vaccinated pigs are in a better clinical condition in comparison with the control group. Morbidity in the rearing period was reduced from $16.3 \%$ in the control group to $6.0 \%$ in vaccinated pigs, and in the fattening period, respectively, from $30.6 \%$ in the control group to $10.0 \%$ in the vaccinated group. Pathological features in the lung characteristic for the enzootic pneumonia in the vaccinated pigs were reduced from $25.5 \% \pm 7.24$ to $4.0 \% \pm 2.44$, and PCVI from $13.0 \% \pm 4.66$ to $0 \%$. Vaccination of pigs has been received and a higher average daily gain in groups for rearing $(0.624 \mathrm{~kg})$ and for fattening $(0.723 \mathrm{~kg})$ was recorded.
\end{abstract}

Key words: Enzootic pneumonia, Mycoplasma hyopneumoniae, pigs, vaccination

\section{INTRODUCTION}

Porcine enzootic pneumonia (EP) is a chronic respiratory disease caused by Mycoplasma hyopneumoniae ( $M$. hyopneumoniae, M. hyo) (13). This is one of the most common respiratory diseases in swine and causes considerable economic

Corresponding author: Dr. Roman Pepovich, PhD.

E-mail address:rpepovich@abv.bg

Present address: Department of Infectious Pathology \& Hygiene, Technology and Control of Food of Animal Origin,

Faculty of Veterinary Medicine, University of Forestry, Sofia, Bulgaria Phone: +35987 7311511

Copyright: (C) 2015 Pepovich R. This is an open-access article published under the terms of the Creative Commons Attribution License which permits unrestricted use, distribution, and reproduction in any medium, provided the original author and source are credited.

Competing Interests: The authors have declared that no competing interests exist.

Available Online First: 24 July 2015

http://dx.doi.org/10.14432/j.macvetrev.2015.07.051 losses worldwide as a result of poor feed efficiency, growth retardation, higher morbidity and mortality, emergency slaughter and prophylaxis and treatment costs $(2,5,11)$.

Immunoprophylaxis is a key tool in the overall infection control program. Although the existing vaccines do not prevent lung colonization by $M$. hyo, what they do provide is partial protection against pathological changes in organs (9). Vaccination has a marked positive effect: improvement of clinical signs, reduced severity of pathological lesions in the lungs, improvement in mean daily gain, shorter fattening period, and last but not least, lower mortality $(3,10,12,14,15)$.

Eggen et al. (4) studied the effect of different combinations of $M$. hyo and porcine circovirus type $2(P C V 2)$ vaccines in swine and reported that 
following single-dose vaccination, the lung lesions decreased with $53 \%$ to $61 \%$ and the antibody titer against $P C V 2$ continued to increase up to 10 weeks of age. The authors suggest that there is no immunological interference between $M$. hyo and $P C V 2$ in the tested combinations and that there is little difference in the antibody titer against $P C V 2$ between the groups given a single combined vaccine and those given the two vaccines separately.

The aim of the present study was to assess and analyze the prophylactic effect of a combined vaccine against enzootic pneumonia in industrial pig farming in Bulgaria.

\section{MATERIAL AND METHODS}

\section{Animals}

The study was carried out on a pig-breeding and fattening farm where manifestations of porcine respiratory disease complex (PRDC) - with enzootic pneumonia as the main etiological agent-had been noted. The study included 100 animals at the same age and live weight. They were equally divided into two groups:

Group 1: Pigs $(\mathrm{n}=50)$ were given a single dose of the combined inactivated vaccine $(M$. hyo $+P C V 2)$ on day 21 after birth. The vaccine was administered intramuscularly (IM) at a $2 \mathrm{ml}$ dose, according to the manufacturer's instructions.

Group 2: Pigs $(\mathrm{n}=50)$ were not vaccinated and served as a control group.

The animals from the two groups were reared under the same conditions.

\section{Clinical examinations}

All animals were subjected to clinical examinations during the experimental period. The examinations included overall condition (febrility, conjunctivitis, appetite, discomfort, nutritional status) and clinical signs characteristic of porcine respiratory infections (respiratory distress, cough, discharge from nostrils). The clinical condition of the animals was evaluated on the basis of a four-point scale: very good $(++++)$; good $(+++)$; satisfactory $(++)$ and poor $(+)$.

\section{Pathological lesions}

Autopsy was performed on animals that died during the experiment. At the end of the fattening period the lungs of all animals were examined and the size, type and severity of the lung lesions were scored. The severity of macroscopic changes in lung-specific enzootic pneumonia was determined by quantification of the damage described by Kristensen et al. (8). Individual lobes represent 196 a percentage of the total area of the lungs: right apical lobe (10\%); right cardiac lobe (10\%); right diaphragmatic lobe (35\%); right accessory lobe (5\%); left apical lobe (5\%); left cardiac lobe (5\%); left diaphragmatic lobe (30\%).

\section{Serological analyses}

Before vaccination, a total of 16 blood samples were taken ( 8 samples per group) and were analyzed by blocking ELISA (Oxoid) for the presence of antibodies against $M$. hyopneumoniae glycoprotein $74 \mathrm{KDa}$. Two negative and two positive controls were included, according to the manufacturer's instructions. Optical density (OD) was measured monochromatically at $450 \mathrm{~nm}$.

\section{DNA extraction and Polymerase Chain Reaction (PCR)}

DNA was extracted from $20-50 \mathrm{mg}$ lung tissue samples. The samples were incubated with $20 \mu \mathrm{L}$ of proteinase $\mathrm{K}(10 \mathrm{mg} / \mathrm{mL})$ and $400 \mu \mathrm{L}$ of reagent $\mathrm{B}$ (10 m MTris, $1 \mathrm{mM}$ EDTA and $0.1 \mathrm{M} \mathrm{NaCl}$ ) at $50^{\circ} \mathrm{C}$ for at least $3 \mathrm{~h}$ or overnight. Following centrifugation for $3 \mathrm{~min}$ at $3000 \mathrm{rpm}, 400 \mu \mathrm{L}$ of the supernatant were mixed with $400 \mu \mathrm{L}$ of reagent $\mathrm{C}$ (Trissaturated phenol and chlorophorm : isoamyl alcohol (24:1) in a 1:1 ratio), vortexed and centrifuged at $13000 \mathrm{rpm}$ for $5 \mathrm{~min}$. The supernatant was pipetted into another microtube and an equivalent amount of chlorophorm/isoamyl alcohol (at a 24:1 ratio) was added. After vortexing and centrifugation for $5 \mathrm{~min}$ at $13000 \mathrm{rpm}$, the supernatant was again pipetted into a new microtube and mixed with $100 \%$ ethanol (Merck, Germany) in a 1:2 ratio; and $5 \mu \mathrm{L}$ of $7 \mathrm{M}$ ammonium citrate (Sigma, USA) were added. The samples were then left to precipitate for 30 min at $-20^{\circ}$ $\mathrm{C}$, and were centrifuged at $13000 \mathrm{rpm}$ for $15 \mathrm{~min}$. The resulting supernatant was discarded and the pellet was washed with cold $70 \%$ ethanol and centrifuged at $13000 \mathrm{rpm}$ for $2 \mathrm{~min}$. The resulting pellet was dried for $7 \mathrm{~min}$ and dissolved in $20-50 \mathrm{~mL}$ distilled water.

PCR reactions were performed with the primers and protocol described by Villarreal et al. (15) with modifications (annealing at $53.5^{\circ} \mathrm{C}$ for $40 \mathrm{~s}$ ). The reaction mixtures contained: $3.0 \mu \mathrm{L}$ of DNA, $10 \mathrm{pmol}$ of each primer, $12.5 \mu \mathrm{L}$ of $2 \mathrm{x}$ PCR Master Mix (Geneshun Biotech co. ltd, China) and distilled water to a volume of $25 \mu \mathrm{L}$.

The quantity and quality of the extracted DNA and the PCR products were analyzed by $2 \%$ agarose gel electrophoresis (Geneshun Biotech co. ltd, China), with $10 \mathrm{mg} / \mathrm{mL}$ ethidium bromide (Sigma, USA) staining and a $100 \mathrm{bp}$ DNA Ladder (Geneshun Biotech Co. ltd, China), at $120 \mathrm{~V}$ for $40 \mathrm{~min}$. 
Clinical testing of combined enzootic pneumonia vaccine in pig farming

Statistical analysis

All results were processed statistically by the use of computer software StatMost (StatMost 3.6, Dataxiom Software, 2003). The results are presented as mean with standard error (mean $\pm S E$ ), after application of the one-way ANOVA statistic. Statistically significant differences were accepted at $p<0.05$.

\section{RESULTS}

During the suckling period -from birth to weaning- no clinically infected pigs were observed. One pig from the control group died and the pathoanatomical examination showed lesions typical for EP and Actinobacillus pleuropneumoniae (APP). In the group of animals which were administered the combined vaccine $(M . h y o+P C V 2)$, there was a $0.538 \mathrm{~kg}(\mathrm{p}<0.01)$ higher weight gain (Table 1$)$.

All the animals from group $1(\mathrm{n}=50)$ as well as 49 animals from group 2 continued into the growing period (Table 2), which continued for 73 days. During the growing period, there were no deaths, but the morbidity of the control group increased sharply to reach $16.3 \%$ in comparison to $6 \%$ in the group of the vaccinated animals. In this period, the vaccinated animals showed higher mean daily gain (up to $0.624 \mathrm{~kg}$ ) than the non-vaccinated ones $(0.512 \mathrm{~kg})$.

Table 1. Business and economic outcomes in experimental piglets vaccinated with combination vaccine (M. hyo $+P C V 2)$ and unvaccinated

\begin{tabular}{lccc}
\hline \multicolumn{1}{c}{ Parameters } & Units & $\begin{array}{c}\text { I group } \\
\text { (M. hyo+PCV2) }\end{array}$ & $\begin{array}{c}\text { II group } \\
\text { (Control) }\end{array}$ \\
\hline 1. Pigs in the group & number & 50 & 50 \\
\hline 2. Average live weight at birth & $\mathrm{\kappa g}$ & $1.200 \pm 2.23^{*}$ & $1.200 \pm 1.89$ \\
\hline 3. Stay in group "piglets" & days & 35 & 35 \\
\hline \multirow{2}{*}{ 4. Diseased } & number & 0 & 0 \\
\cline { 2 - 4 } & $\%$ & 0 & 0 \\
\hline \multirow{2}{*}{ 5. Died from PRDC } & number & 0 & 1 \\
\cline { 2 - 4 } & $\%$ & 0 & 2 \\
\hline \multirow{2}{*}{ 6. Average live weight at the end of the period } & $\mathrm{\kappa g}$ & $9.090 \pm 2.58^{* *}$ & 100 \\
\hline \multirow{2}{*}{ 7. Derived growth period } & $\%$ & 106.3 & 7.352 \\
\hline \multirow{2}{*}{ 8. Average daily gain } & $\mathrm{\kappa g}$ & 7.890 & 100 \\
\cline { 2 - 4 } & $\%$ & 107.3 & 0.210 \\
\hline
\end{tabular}

$* p<0.05 \quad * * p<0.01 \quad * * * p<0.001$

Table 2. Business and economic outcomes in the experimental weaners pigs vaccinated with combination vaccine (M. hyo $+P C V 2)$ and unvaccinated

\begin{tabular}{lccc}
\hline \multicolumn{1}{c}{ Parameters } & Units & $\begin{array}{c}\text { I group } \\
\text { (M. hyo+PCV2) }\end{array}$ & $\begin{array}{c}\text { II group } \\
\text { (Control) }\end{array}$ \\
\hline 1. Pigs in the group & number & 50 & 49 \\
\hline 2. Average live weight at beginning of period & $\mathrm{kg}$ & $9.090 \pm 2.58^{*}$ & $8.552 \pm 3.02$ \\
\hline 3. Stay in weaners & days & 73 & 73 \\
\hline \multirow{2}{*}{ 4. Average live weight at the end of the period } & $\mathrm{\kappa g}$ & $54.634 \pm 3.07^{*}$ & $45.905 \pm 3.64$ \\
\cline { 2 - 4 } & $\%$ & 119 & 100 \\
\hline \multirow{2}{*}{ 5. Diseased } & number & 3 & 16.3 \\
\hline \multirow{2}{*}{ 6. Died from PRDC } & $\%$ & 6 & 0 \\
\hline \multirow{2}{*}{ 7. Derived growth period } & number & 0 & 0 \\
\hline \multirow{2}{*}{ 8. Average daily gain } & $\%$ & 0 & 37.353 \\
\cline { 2 - 4 } & $\mathrm{\kappa g}$ & 45.544 & 100 \\
\hline
\end{tabular}

$* p<0.05 \quad * * p<0.01 \quad * * * p<0.001$


During the fattening period (94 days), the mean live weight was $8.729 \mathrm{~kg}$ higher in the group of vaccinated pigs than in the control (non-vaccinated) group. There were also no deaths. However, clinical signs of a respiratory infection were evident in $10 \%$ of the vaccinated pigs and in $30.6 \%$ of the control ones. The live weight measured at regular slaughter of animals from both groups was shown to be $19.6 \mathrm{~kg}$ $(p<0.05)$ higher in the vaccinated animals as compared to the non-vaccinated ones (Table 3).

Details about the overall and the clinical condition of the pigs during the growing and the fattening period are given in Table 4 and Table 5.
Table 6 presents the results from the pathoanatomical examinations and the observed lesions in the vaccinated and non-vaccinated pigs. The pathoanatomical findings in the lungs of both groups of animals were similar: for EP, APP and PCVI. In the vaccinated animals, the number of lesions characteristic of EP was reduced from $25.5 \% \pm 7.24(p<0.01)$ to $4 \% \pm 2.44(p<0.01)$, and of PCVI, from $13 \% \pm 4.66(p<0.05)$ in the control group to $0 \%(p<0.05)$ in the vaccinated group. The lesions typical for APP amounted to $11.5 \% \pm 7.67$ in the control group, but were reduced to $2.0 \% \pm 1.10$ owing to the vaccination.

Table 3. Business and economic outcomes in the experimental fattening pigs vaccinated with combination vaccine (M. hyo $+P C V 2)$ and unvaccinated

\begin{tabular}{|c|c|c|c|}
\hline Parameters & Units & $\begin{array}{c}\text { I group } \\
\text { (M. hyo+PCV2) }\end{array}$ & $\begin{array}{l}\text { II group } \\
\text { (Control) }\end{array}$ \\
\hline 1. Pigs in the group & number & 50 & 49 \\
\hline 2. Average live weight at beginning of period & $\mathrm{\kappa g}$ & $54.634 \pm 3.07^{*}$ & $45.905 \pm 3.64$ \\
\hline 3. Stay in group fattening & days & 94 & 94 \\
\hline \multirow{2}{*}{ 4. Average live weight at the end of the period } & кg & $122.6 \pm 2.06^{*}$ & $103.0 \pm 1.98$ \\
\hline & $\%$ & 119 & 100 \\
\hline \multirow{2}{*}{ 5. Derived growth period } & кg & 68.0 & 57.0 \\
\hline & $\%$ & 119.3 & 100 \\
\hline \multirow{2}{*}{ 6. Average daily gain } & кg & 0.723 & 0.607 \\
\hline & $\%$ & 119.1 & 100 \\
\hline \multirow{2}{*}{ 7. Diseased } & number & 5 & 15 \\
\hline & $\%$ & 10 & 30.6 \\
\hline \multirow{2}{*}{ 8. Died from PRDC } & number & 0 & 0 \\
\hline & $\%$ & 0 & 0 \\
\hline \multirow{2}{*}{ 9. Slaughtered «economic foreshore» } & number & 1 & 4 \\
\hline & $\%$ & 2 & 8 \\
\hline$* * p<0.01$ & & & \\
\hline
\end{tabular}

Table 4. Total and clinical state of the experimental pigs in the two groups during the period of «rearing» vaccinated with combination vaccine $(M$. hyo $+P C V 2)$ and unvaccinated

\begin{tabular}{|c|c|c|c|c|c|c|c|c|}
\hline \multirow{3}{*}{$\begin{array}{l}\text { Clinical condition of } \\
\text { the experimental pigs }\end{array}$} & \multicolumn{4}{|c|}{$\begin{array}{c}\text { Rearing - } \\
\text { first period } \\
(8-12 \mathrm{~kg})\end{array}$} & \multicolumn{4}{|c|}{$\begin{array}{c}\text { Rearing - } \\
\text { second period } \\
(12-40 \mathrm{~kg})\end{array}$} \\
\hline & \multicolumn{2}{|c|}{$\begin{array}{c}\text { I group } \\
\text { (M. hyo+PCV2) } \\
\mathrm{n}=50\end{array}$} & \multicolumn{2}{|c|}{$\begin{array}{c}\text { II group } \\
\text { (Control) } \\
n=49\end{array}$} & \multicolumn{2}{|c|}{$\begin{array}{c}\text { I group } \\
\text { (M. hyo+PCV2) } \\
n=50\end{array}$} & \multicolumn{2}{|c|}{$\begin{array}{c}\text { II group } \\
\text { (Control) } \\
n=49\end{array}$} \\
\hline & number & $\%$ & number & $\%$ & number & $\%$ & number & $\%$ \\
\hline $\begin{array}{c}\text { Very good } \\
(++++)\end{array}$ & 28 & 56 & 11 & 22.4 & 22 & 44 & 8 & 16.3 \\
\hline $\begin{array}{c}\text { Good } \\
(+++)\end{array}$ & 17 & 34 & 21 & 42.9 & 23 & 46 & 22 & 44.9 \\
\hline $\begin{array}{l}\text { Satisfactory } \\
(++)\end{array}$ & 3 & 6 & 12 & 24.5 & 4 & 8 & 16 & 32.7 \\
\hline $\begin{array}{c}\text { Poor } \\
(+)\end{array}$ & 2 & 4 & 5 & 10.2 & 1 & 2 & 3 & 6.1 \\
\hline $\begin{array}{l}\text { Mean } \\
\pm \text { SE }\end{array}$ & $\begin{array}{c}12.5 \\
\pm 6.19\end{array}$ & $\begin{array}{l}25.0^{* * *} \\
\pm 12.39\end{array}$ & $\begin{array}{c}12.3 \\
\pm 3.30\end{array}$ & $\begin{array}{l}25.0^{* * * *} \\
\pm 6.74\end{array}$ & $\begin{array}{c}12.5 \\
\pm 5.80\end{array}$ & $\begin{array}{c}25.0 \\
\pm 11.61\end{array}$ & $\begin{array}{c}12.3 \\
\pm 4.21\end{array}$ & $\begin{array}{c}25.0 \\
\pm 8.60\end{array}$ \\
\hline$* p<0.05$ & 0.01 & $* * * p<$ & & & & & & \\
\hline
\end{tabular}


Clinical testing of combined enzootic pneumonia vaccine in pig farming

Table 5. Total and clinical state of the experimental pigs in the two groups during the period of "fattening" vaccinated with combination vaccine $(M$. hyo $+P C V 2)$ and unvaccinated

\begin{tabular}{|c|c|c|c|c|c|c|c|c|}
\hline \multirow{3}{*}{$\begin{array}{l}\text { Clinical condition of } \\
\text { the experimental pigs }\end{array}$} & \multicolumn{4}{|c|}{$\begin{array}{l}\text { Fattening - } \\
\text { first period } \\
(40-70 \mathrm{Kg})\end{array}$} & \multicolumn{4}{|c|}{$\begin{array}{c}\text { Fattening - } \\
\text { second period } \\
(70-105 \mathrm{~kg})\end{array}$} \\
\hline & \multicolumn{2}{|c|}{$\begin{array}{c}\text { I group } \\
\text { (M. hyo+PCV2) } \\
n=50\end{array}$} & \multicolumn{2}{|c|}{$\begin{array}{c}\text { II group } \\
\text { (Control) } \\
\mathrm{n}=49\end{array}$} & \multicolumn{2}{|c|}{$\begin{array}{c}\text { I group } \\
\text { (M. hyo+PCV2) } \\
n=50\end{array}$} & \multicolumn{2}{|c|}{$\begin{array}{c}\text { II group } \\
\text { (Control) } \\
\mathrm{n}=49\end{array}$} \\
\hline & number & $\%$ & number & $\%$ & number & $\%$ & number & $\%$ \\
\hline $\begin{array}{c}\text { Very good } \\
(++++)\end{array}$ & 20 & 40 & 6 & 12.2 & 26 & 52 & 5 & 10.2 \\
\hline $\begin{array}{l}\text { Good } \\
(+++) \\
\end{array}$ & 23 & 46 & 19 & 38.8 & 22 & 44 & 15 & 30.6 \\
\hline $\begin{array}{c}\text { Satisfactory } \\
\quad(++)\end{array}$ & 2 & 4 & 9 & 18.4 & 1 & 2 & 25 & 51 \\
\hline $\begin{array}{c}\text { Poor } \\
(+)\end{array}$ & 5 & 10 & 15 & 30.6 & 1 & 2 & 4 & 8.2 \\
\hline $\begin{array}{l}\text { Mean } \\
\pm \text { SE }\end{array}$ & $\begin{array}{c}12.5 \\
\pm 5.26\end{array}$ & $\begin{array}{c}25.0 \\
\pm 10.53\end{array}$ & $\begin{array}{c}12.3 \\
\pm 2.92\end{array}$ & $\begin{array}{c}25.0 \\
\pm 5.98\end{array}$ & $\begin{array}{l}12.5 \\
\pm 6.68\end{array}$ & $\begin{array}{c}25.0 \\
\pm 13.37\end{array}$ & $\begin{array}{c}12.3 \\
\pm 4.92\end{array}$ & $\begin{aligned} & 25.0 \\
\pm & 10.03\end{aligned}$ \\
\hline$* p<0.05$ & 0.01 & $* * * p$ & & & & & & \\
\hline
\end{tabular}

Table 6. Results of pathology examinations at regular slaughter of pigs in experimental groups

\begin{tabular}{|c|c|c|c|c|c|c|}
\hline \multirow{3}{*}{$\begin{array}{l}\text { № of } \\
\text { pigs }\end{array}$} & \multicolumn{3}{|c|}{$\begin{array}{l}\text { I group vaccinated with } \\
\text { "M. hyo+PCV2" }\end{array}$} & \multicolumn{3}{|c|}{$\begin{array}{l}\text { II group unvaccinated } \\
\text { "Control" }\end{array}$} \\
\hline & \multicolumn{3}{|c|}{$\begin{array}{l}\% \text { of changes in } \\
\text { the lungs }\end{array}$} & \multicolumn{3}{|c|}{$\begin{array}{l}\% \text { of changes in } \\
\text { the lungs }\end{array}$} \\
\hline & EP & APP & PCVI & EP & APP & PCVI \\
\hline 1 & 0 & 0 & 0 & 50 & 0 & 0 \\
\hline 2 & 0 & 0 & 0 & 75 & 30 & 0 \\
\hline 3 & 25 & 0 & 0 & 30 & 0 & 0 \\
\hline 4 & 5 & 0 & 0 & 30 & 0 & 20 \\
\hline 5 & 5 & 0 & 0 & 20 & 10 & 25 \\
\hline 6 & 5 & 0 & 0 & 0 & 0 & 0 \\
\hline 7 & 0 & 5 & 0 & 0 & 0 & 40 \\
\hline 8 & 0 & 0 & 0 & 20 & 75 & 0 \\
\hline 9 & 0 & 5 & 0 & 10 & 0 & 25 \\
\hline 10 & 0 & 10 & 0 & 20 & 0 & 20 \\
\hline $\begin{array}{l}\text { Mean } \\
\pm \text { SE }\end{array}$ & $\begin{array}{l}4.0 \% \%^{* *} \\
\pm 2.44\end{array}$ & $\begin{array}{l}2.0 \% \\
\pm 1.10\end{array}$ & $\begin{array}{c}0 \%{ }^{*} \\
\pm 0\end{array}$ & $\begin{array}{c}25.5 \%^{* *} \\
\pm 7.24\end{array}$ & $\begin{array}{c}11.5 \% \\
\pm 7.67\end{array}$ & $\begin{array}{c}13.0 \% \\
\pm 4.66\end{array}$ \\
\hline$* p<0.05$ & $* * p<0.01$ & $* * * p$ & & & & \\
\hline
\end{tabular}

\section{DISCUSSION}

The efficacy of a single dose of the combined inactivated vaccine $(M$. hyo $+P C V 2)$ on day 21 after birth of the pigs was demonstrated by the date of the vaccination in a farm, where manifestations of PRDC with enzootic pneumonia as the main etiological agent had been noted.

The results related to the overall and the clinical condition of the pigs during the growing and the fattening period indicate that, as a whole, the vaccinated pigs were in a better condition and with better health than those in the control group. The vaccination led to a reduction in the percentage of animals with signs associated with poor clinical outcomes.

The results of the serological tests before vaccination show that the studied serum 16 (8 sera from both groups) in pigs in the experimental group did not show specific antibodies against $M$. hyopneumoniae, and in the control group 6 samples reacted positive $(75 \%)$. When examining the antibody titers against $M$. hyopneumoniae, three weeks after application of the combined vaccine it 
was found that of the test samples $17-13(76.5 \%)$ reacted positive. These animals had an intense and protective immune response. In the sera of 3 pigs $(17.6 \%)$ vaccine antibodies were not detected, in a pig from group $1(5.9 \%)$ the results are questionable. In the control group of 17 analyzed samples, 16 samples $(94.1 \%)$ had negative titers and in 1 sample $(5.9 \%)$ they were dubious. Analysis of the results of serological tests on samples obtained at the end of the fattening period, shows that in pigs vaccinated with a combination vaccine, out of 6 samples in 2 $(33.3 \%)$ there were antibodies against $M$. hyo. In the control group the results are similar. In conclusion, we can say that high titers of maternal antibodies induced by infection or vaccination, have had a negative effect on vaccination of pigs, which is confirmation of the data exported from Jayappa et al.

(7) and Hodgins et al. (6).

Since established pathomorphological changes are characteristic and typical for enzootic pneumonia, but not specific, then contact differentiating them from changes caused by other participants in the PRDC, especially swine influenza (SI) was established through conducting a molecular biological research. Of the 14 examined lungs with lesions typical of EP by a conventional PCR, the DNA of M. hyopneumoniae was detected in 5 samples (35.7\%). 4 samples (28.6\%) are suspicious and 5 samples (35.7\%) were negative.

Aiguo et al., (1) demonstrated the improvement of productivity in a Chinese farm with a continuous production system by implementing combination vaccine $(M$. hyo $+P C V 2)$. The vaccines are mixed before using and thus they save labor and reduce stress for the piglets. Similar to our results, they established that total mortality and the culling rate during the nursery and fattening period was reduced (5.26\% in the vaccinated group), as well as the clinical signs.

Our results demonstrate that the combined vaccine against $M$. hyo and $P C V 2$ has good prophylactic efficacy not only in terms of reduction of clinical signs and good overall condition of the animals, but in higher mean daily gain in the growing $(0.624 \mathrm{~kg})$ and the fattening period $(0.723 \mathrm{~kg})$. The vaccination also contributed to the decrease in the degree and severity of the pathoanatomical lesions characteristic of EP and PCVI in the lungs of slaughtered pigs. These results are in agreement with other investigations $(3,10,12,14)$ who report a good prophylactic effect of vaccination, despite the fact that it does not render pigs completely immune against $M$. hyo infection.

\section{ACKNOWLEDGMENTS}

This research work was carried out with the support of University of Forestry and the project BG051PO001-3.3.06-0056 "Support for the development of young people in the University ofForestry", Operational Programme "Human Resources Development" financed by the European Social Fund of the European Union.

\section{REFERENCES}

1. Aiguo, W., Yanlong Li, Longquan Yao, Liande Zhu, Tan Tao. (2013). Efficacy of Ingelvac Mycoflex ${ }^{\circledR}$.

2. In a chinese farm. The 6th Asian Pig Veterinary Society Congress Ho Chi Minh City, Vietnam, September 23-25, 2013. PO35.

3. Dawson, A., Harvey, R.E., Thevasagayam, S.J., Sherington, J. (2002). Studies of the field efficacy and safety of a single-dose Mycoplasma hyopneumoniae vaccine for pigs. Vet. Rec., 151, 535-538.

http://dx.doi.org/10.1136/vr.151.18.535

PMid:12448490

4. Eggen, A., Schmidt, U., Raes, M., Witvliet, M. (2010). One-dose vaccination against $M$. hyo and PCV2. Pig Progress, 23.

5. Georgakis, A.D., Bourtzi-Hatzopoulou, E., Kritas, S.K., Balkamos, G.C., Kyriakis, S.C. (2002). A study on the Porcine Respiratory Disease Syndrome (PRDC): Update review and proposed measures for its control. J Hellenic Vet Med Society 53, 265-271.

6. Hodgins, D., Shewen, P., Dewey, C. (2004). Influence of age and maternal antibodies on antibody responses of neonatal piglets vaccinated against Mycoplasma hyopneumoniae. J. Swine Hlth. Prod. 12, 10-16.

7. Jayappa, H., Davis, B., Rapp-Gabrielson, V., Wasmoen, T., Thacker, E. (2001). Evaluation of the efficacy of Mycoplasma hyopneumoniae bacterin following immunization of young pigs in the presence of varying levels of maternal antibodies. In: Proc. $32^{\text {nd }}$ Annual Meeting Am. Assoc. Swine Vet., Nashville, Tennessee, 237-241.

8. Kristensen, Ch., Vinther, J., Svensmark, B., Baekbo, P. (2014). A field evaluation of two vaccines against Mycoplasma hyopneumoniae infection in pigs. Acta Veterinaria Scandinavica, 56, 24, 1-7. http://dx.doi.org/10.1186/1751-0147-56-24

9. Maes, D., Deluyker, H., Verdonck, M., Castryck, F., Miry, C., Vrijens, B., Verbeke, W., Viaene, J., De Kruif, A. (1999). Effect of vaccination against Mycoplasma hyopneumoniae in pig herds with an allin/all-out production system. Vaccine. 17, 1024-1034. http://dx.doi.org/10.1016/S0264-410X(98)00254-0 
10. Maes, D., Verbeke, W., Vicca, J., Verdonck, M., De Kruif, A. (2003). Benefit to cost of vaccination against Mycoplasma hyopneumoniae in pig herds under Belgian market conditions from 1996 to 2000. Livestock Production Science. 83, 85-93. http://dx.doi.org/10.1016/S0301-6226(03)00039-3

11. Maes, D., Segales, J., Meyns, T., Sibila, M., Pieters, M., Haesebrouck, F. (2008). Control of Mycoplasma hyopneumoniae infections in pigs. Vet. Microbiol. 126, 297-309.

http://dx.doi.org/10.1016/j.vetmic.2007.09.008

PMid:17964089

12. Pallares, F.J., Gomez, S., Munoz, A. (2001). Evaluation of zootechnical parameters of vaccinating against swine enzootic pneumonia under ield conditions. Vet. Rec. 148, 104-107.

http://dx.doi.org/10.1136/vr.148.4.104

PMid:11232924
13. Thacker, E. L (2006). Mycoplasmal diseases. In: Leman, A.D., Straw, B.E., D’Allaire, S., Mengeling, W.L., and Taylor, D.J., (Ed.), Diseases of Swine, $9^{\text {th }}$ ed. The Iowa State University Press, Ames, IA, [701-717.

14. Wallgren, P., Vallgarda, J., Lindberg, M., Eliason-Selling, L. (2000). The efficacy of different vaccination strategies against Mycoplasma hyopneumoniae. In Proc. of the 16-th IPVS Congress, Melbourne, Australia, 461.

15. Villarreal, I., Vranckx, K., Duchateau, L., Pasmans, F., Haesebrouck, F., Jensen, J., Nanjiani, L., Maes, D. (2010). Early Mycoplasma hyopneumoniae infections in European suckling pigs in herds with respiratory problems: detection rate and risk factors. Veterinarni Medicina. 55, 7, 318-324. 